\title{
Phyto-availability of chromium to fluted pumpkin (Telfairia occidentalis Hook F.) in an ultisol
}

\section{Ehi R obert Orhue* and Uzu Frank}

Department of Soil Science, Faculty of Agriculture, University of Benin, P.M.B. 1154, Benin City, Edo State, NIGERIA *Corresponding author. E-mail: orhuerob@yahoo.com

Abstract: The present study was conducted to determine the influence of $\mathrm{Cr}$ on some agronomic characters of Telfairia occidentalis nutrient content and uptake and some chemical properties of soil. In the greenhouse trial, chromium nitrate $\left[\mathrm{Cr}\left(\mathrm{NO}_{3}\right)_{2}\right]$ was applied at rates of $0,50,100$ and $200 \mathrm{mg}$ per $5 \mathrm{~kg}$ sieved and air-dried soil obtained from a depth of $0-15 \mathrm{~cm}$. The rates of $0,20,40$ and $80 \mathrm{kgha}^{-1}$ equivalent to pot rates were used in the field trial. Results showed that the soil used was texturally sandy loam and an ultisol as revealed by its low base saturation. In the greenhouse the soil $\mathrm{pH}, \mathrm{N}, \mathrm{K}, \mathrm{Mg}, \mathrm{Ca}, \mathrm{Na}, \mathrm{Fe}, \mathrm{Mn}, \mathrm{Zn}$, free $\mathrm{Fe}$ and $\mathrm{Al}$ oxides, organic carbon, effective cation exchange capacity, exchangeable acidity, amorphous $\mathrm{Fe}$ and $\mathrm{Al}$ oxides content of the soil decreased inconsistently at various levels of $\mathrm{Cr}$ treatments except available $\mathrm{P}$, which appreciated inconsistently. With the exception of soil pH, organic carbon, available $\mathrm{P}$ and amorphous $\mathrm{Fe}$ oxide, which increased at various levels of $\mathrm{Cr}$ concentrations, all other soil chemical properties determined, declined inconsistently in the field trial. The amorphous Al oxide however remained stable in the field trial. The $\mathrm{Cr}$ content of the soil increased with the levels of $\mathrm{Cr}$ treatments when compared with the control in the trials. The $\mathrm{N}, \mathrm{P}, \mathrm{K}, \mathrm{Mg}, \mathrm{Ca}, \mathrm{Na}, \mathrm{Fe}, \mathrm{Mn}$ and $\mathrm{Zn}$ content of shoot and root as well as their uptake also decreased consistently with increasing $\mathrm{Cr}$ treatments. In addition, the $\mathrm{Cr}$ content as well as uptake by the shoot and root also increased consistently with increased rates of the $\mathrm{Cr}$ applied in the trials with the minimum levels of the $\mathrm{Cr}$ content and uptake recorded at the control treatments. As the $\mathrm{Cr}$ concentration increased, the crude protein content of both shoot and root consistently decreased with highest crude protein content recorded in the shoot compared to the root. A decrease in the dry matter yield with increased $\mathrm{Cr}$ treatments in shoot and root was recorded in the trials. Results also showed that the $\mathrm{Cr}$ influenced the height, collar girth, leaf area and number of leaves with control treatments higher than other treatments at final harvest.

Keywords: Chromium, Phyto-availabilty, Uptake, Protein, Mineral ions

\section{INTRODUCTION}

Chromium $(\mathrm{Cr})$ is naturally found in the soil. It accumulates with iron in weathering residue and rarely at toxic level. Nowadays, the presence of $\mathrm{Cr}$ in the environment is widespread due to its usage in many industrial processes such as tanning, metallurgic and plating industries e.t.c. The disposal of this $\mathrm{Cr}$ into the environment ends up in the soil. The phyto-availability of $\mathrm{Cr}$ depends on the speciation state and nature of plant species. The $\mathrm{Cr}$ is thermodynamically stable in two oxidative states namely $\mathrm{Cr}$ (IV) considered to be mobile in the soil and $\mathrm{Cr}$ (III) which is less mobile and strongly attaches to soil particles.

Plants only take up $\mathrm{Cr}$ (III) at low concentration but when concentrations exceed certain level, negative effects occur. Shaganas et al. (1997) reported that high Cr associated with the soil components significantly reduced the length of shoot and root of Vignas radiata. Also Subramani et al. (1997) observed gradual decline in growth parameters of Vigna mungo with increase in the concentration of $\mathrm{Cr}$. Chromium has also been reported to affect water status and mineral nutrition of bean plant (Azmat and Khanum, 2005).

One of the ways man can be ingest $\mathrm{Cr}$ is through the consumption of crops such as fluted pumpkin. The plant fluted pumpkin leaves and seeds are widely consumed in tropical Africa. It is highly nutritive with many minerals. This study therefore was undertaken to (i) determine the effect of $\mathrm{Cr}$ on some agronomic characters of the plant, (ii) determine parts of the plant with highest ability to accumulate $\mathrm{Cr}$ (iii) determine the effect of $\mathrm{Cr}$ on some mineral content as well as their uptake (iv) determine effect of $\mathrm{Cr}$ on some chemical components of the soil.

\section{MATERIALS AND METHODS}

Site of the trial:The greenhouse and field trials were conducted at the Faculty of Agriculture experimental site, University of Benin, Benin City, Nigeria.

Greenhouse trial: In the greenhouse study, soil samples were collected from surface $0-15 \mathrm{~cm}$ depth of soil. The soil collected was bulked, mixed thoroughly, air dried and sieved to remove debris. Thereafter, $5 \mathrm{~kg}$ of the composite soil was weighed and put in the various plastic pots. The 
total number of plastic pots used was 48 with each plastic pot labeled for the various treatments. Each replicate had 16 plastic pots with 4 pots per treatment. The chromium nitrate $\left[\mathrm{Cr}\left(\mathrm{NO}_{3}\right)_{2}\right]$ used was applied at $0,50,100,200 \mathrm{mg}$ per $5 \mathrm{~kg}$ soil. The applied heavy metal was thoroughly mixed with the soil and then left for 7 days to enable the heavy metal equilibrate with the soil. The experiment was laid out in a completely randomized design with three replicates. Before transplanting the seedlings, the soil was moistened to field capacity with distilled water. The plants were watered with distilled water throughout the period of the crop growth. Excess moisture drainage from perforation at the base of each pot was collected by a saucer placed below each pot to prevent leaching into the soil and cross contamination among pots. The plant height, number of leaves, stem girth and leaf area were taken every 10-day intervals till final harvest at 30 days after transplanting when the above-ground biomass was clipped at soil level with stainless steel blade to separate the roots and then carefully rinsed in distilled water. Both the roots and the shoot were oven dried in ventilated oven at $72^{\circ} \mathrm{C}$ for $48 \mathrm{hrs}$ to constant dry weight used in computing the nutrient uptake.

Field trial: The field trial was conducted in order to validate results obtained under greenhouse conditions. This field trial was sited where the soil for greenhouse trial was taken. The same heavy metal source as well as levels $(0,50,100,200 \mathrm{mg}$ per $5 \mathrm{~kg}$ soil) equivalent to 0,20 , $40,80 \mathrm{kgCrha}^{-1}$ were used. Each treatment was represented by a bed size of $2.5 \mathrm{~m} \times 2.5 \mathrm{~m}$ separated by 50 $\mathrm{cm}$ space while each replicate was separated by $1 \mathrm{~m}$ alley. The entire experimental site was $12 \mathrm{~m} \mathrm{x} 10 \mathrm{~m}$ giving a total area of $120 \mathrm{~m}^{2}$ The various levels $\left(0,20,40,80 \mathrm{kgCrha}^{-1}\right)$ of the heavy metal were uniformly applied with the aid of a spreader, mixed thoroughly and then left for 7 days before transplanting the seedlings. The experiment was organized in randomized complete block design in three replicates. The pumpkin was sown at a spacing of $1 \mathrm{mx}$ $1 \mathrm{~m}$. Each bed had a plant population of 4 plants. Hand weeding was done regularly. The mode of data collection was similar to that of greenhouse trial.

Soil analysis: Soil samples were collected at the beginning and at the end of the trials to determine the following. The soil $\mathrm{pH}$ was determined at a soil to water ratio of 1:1 using a glass electrode $\mathrm{pH}$ meter. Particle size analysis was determined by the hydrometer method as modified by Day (1965).The organic carbon content of the soil was determined by using the chromic acid wet oxidation procedure as described by Jackson (1962). The nitrogen was determined by micro-kjeldal procedure as described by Jackson (1962) The protein contents were determined using the method of Azmat and Haider, (2007). Phosphorus was extracted by using Bray No. 1 P solution (Bray and Kurtz, 1945) and the P in the extract assayed colorimetrically by the molybdenum blue colour method of Murphy and Riley (1962). The exchangeable bases were extracted using IN neutral ammonium acetate solution $\mathrm{Ca}$ and $\mathrm{Mg}$ content of the extract were determined volumetrically by the EDTA titration procedure (Black, 1965). The K and Na were determined by flame photometry and magnesium content obtained by difference. This was determined by $\mathrm{KCl}$ extraction and titration methods of Mclean (1965). The effective cation exchange capacity was calculated as the sum of exchangeable bases $(\mathrm{Ca}, \mathrm{Mg}, \mathrm{K}$, and $\mathrm{Na}$ ) and exchangeable acidity. The $\mathrm{Cr}$ and oxides were determined by methods of Soon and Abboud (1993). The data generated were analyzed by Genstat statistical version 6.1.0.234 (Payne, 2002).

Plant analysis: The plant materials were ground $(<1 \mathrm{~mm})$ and then digested with a mixture of $\mathrm{HNO}_{3}, \mathrm{H}_{2} \mathrm{SO}_{4}$ and $\mathrm{HCIO}_{4}$ acids (IITA, 1979). The mineral ions (Na, K, Ca, $\mathrm{Mg}, \mathrm{Fe}, \mathrm{Mn}, \mathrm{Zn}$ and $\mathrm{Cr}$ ) were determined by the use of atomic absorption spectrophotometer. For $\mathrm{P}$ content (AOAC, 1970) perchloric acid digestion (wet oxidation) method was used while the micro-kjeldal method of Jackson (1962) was used for $\mathrm{N}$ determination

\section{RESULTS}

Properties of soil used before the trial: The properties of soil used are shown in Table 1. The soil is acidic, texturally sandy loan, low percentage base saturation, $\mathrm{N}, \mathrm{P}, \mathrm{K}, \mathrm{Mg}, \mathrm{Ca}, \mathrm{Na}, \mathrm{Fe}, \mathrm{Mn}, \mathrm{Zn}, \mathrm{Ca}$ and $\mathrm{Cr}$ components. Properties of soil used after greenhouseand field trials: Table 2 reveals the soil properties after the greenhouse and field trials. The $\mathrm{pH}$, organic carbon, $\mathrm{N}, \mathrm{K}, \mathrm{Mg}, \mathrm{Ca}$, $\mathrm{Na}$, exchangeable acidity, effective cation exchange capacity, $\mathrm{Fe}, \mathrm{Mn}, \mathrm{Zn}$, free $\mathrm{Fe}$ and $\mathrm{Al}$ oxides, amorphous $\mathrm{Fe}$ and $\mathrm{Al}$ oxides decreased inconsistently at various levels of $\mathrm{Cr}$ treatments in the greenhouse trial. The available $\mathrm{P}$ and $\mathrm{Cr}$ however appreciated from $3.19 \mathrm{mgkg}^{-}$ ${ }^{1}$ and $0.02 \mathrm{mgkg}^{-1}$ (Table 1) to $4.16 \mathrm{mgkg}^{-1}$ in $0 \mathrm{mgCr}$ and $66.34 \mathrm{mgkg}^{-1}$ in $200 \mathrm{mgCr}$ respectively (Table 2 ).

Similar trend of inconsistent decrease in $\mathrm{N}, \mathrm{K}, \mathrm{Mg}, \mathrm{Na}$, $\mathrm{Ca}, \mathrm{Fe}, \mathrm{Mn}, \mathrm{Zn}$, effective cation exchange capacity, exchangeable acidity, free $\mathrm{Fe}$ and $\mathrm{Al}$ oxides, amorphous $\mathrm{Al}$ oxide also occurred in the field trial. While the soil $\mathrm{pH}$, organic carbon, $\mathrm{P}$, amorphous $\mathrm{Fe}$ oxide increased also inconsistently from $5.64,1.00 \mathrm{gkg}^{-1}, 5.76 \mathrm{mgkg}^{-1}$, $0.08 \%$ (Table 1) to 5.80 in $20 \mathrm{kgCrha}^{-1}, 1.05 \mathrm{gkg}^{-1}$ in 20 kgCrha, $7.03 \mathrm{mgkg}^{-1}$ in $0 \mathrm{kgCrha}^{-1}, 0.11 \%$ in $20 \mathrm{Crkgha}^{-1}$ and $40 \mathrm{kgCrha}^{-1}$ respectively. The amorphous $\mathrm{Al}$ oxide however remained stable whereas the $\mathrm{Cr}$ content of the soil in the entire trial increased also with increase in $\mathrm{Cr}$ treatment.

Effect of $\mathrm{Cr}$ on some miner al content (\% ) and uptake $\left(\mathrm{mgkg}^{-1}\right)$ by the shoot and root of T. occidental is: Table 3 shows the shoot and root mineral components as well as 
Table 1. Physico-chemical properties of soil before the trials.

\begin{tabular}{|c|c|c|}
\hline Properties & Greenhouse value & Field value \\
\hline Soil pH(1:1) & 4.71 & 5.64 \\
\hline Organic carbon $\left(\mathrm{gkg}^{-1}\right)$ & 1.11 & 1.00 \\
\hline Total N (\%) & 0.13 & 0.16 \\
\hline Available $\mathrm{P}\left(\mathrm{mgkg}^{-1}\right)$ & 3.19 & 5.76 \\
\hline $\mathrm{K}\left(\mathrm{cmolkg}^{-1}\right)$ & 0.11 & 0.13 \\
\hline $\operatorname{Mg}\left(\mathrm{cmolkg}^{-1}\right)$ & 0.64 & 0.66 \\
\hline $\mathrm{Ca}\left(\mathrm{cmolkg}^{-1}\right)$ & 0.96 & 0.97 \\
\hline $\mathrm{Na}\left(\mathrm{cmolkg}^{-1}\right)$ & 0.12 & 0.20 \\
\hline Exchangeable acidity & 3.58 & 2.68 \\
\hline $\operatorname{Ecec}\left(\mathrm{mgkg}^{-1}\right)$ & 5.41 & 3.93 \\
\hline $\mathrm{Fe}\left(\mathrm{mgkg}^{-1}\right)$ & 0.03 & 0.04 \\
\hline $\operatorname{Mn}\left(\mathrm{mgkg}^{-1}\right)$ & 0.05 & 0.05 \\
\hline $\mathrm{Zn}\left(\mathrm{mgkg}^{-1}\right)$ & 0.65 & 0.67 \\
\hline $\mathrm{Cr}\left(\mathrm{mgkg}^{-1}\right)$ & 0.02 & 0.02 \\
\hline Percentage base saturation (\%) & 33.83 & 31.81 \\
\hline Free Fe oxide (\%) & 6.38 & 6.40 \\
\hline Free $\mathrm{Al}$ oxide $(\%)$ & 1.73 & 1.21 \\
\hline Amorphous Fe oxide (\%) & 0.07 & 0.08 \\
\hline Amorphous Al oxide (\%) & 0.03 & 0.03 \\
\hline Sand $\left(\mathrm{gkg}^{-1}\right)$ & 865.31 & 864.32 \\
\hline Silt $\left(\mathrm{gkg}^{-1}\right)$ & 12.39 & 14.37 \\
\hline Clay $\left(\mathrm{gkg}^{-1}\right)$ & 122.30 & 121.31 \\
\hline Textural class $\left(\mathrm{gkg}^{-1}\right)$ & Sandy loam & Sandy loam \\
\hline
\end{tabular}

their uptake by the plant. The N, P, K, Mg, Ca, Na, Fe, $\mathrm{Mn}$, and $\mathrm{Zn}$ components of the shoot and root decreased as the concentration of $\mathrm{Cr}$ increased in both the greenhouse and field trials with the control treatments significantly higher than other treatments. In the uptake of $\mathrm{N}, \mathrm{P}, \mathrm{K}, \mathrm{Mg}, \mathrm{Ca}, \mathrm{Na}, \mathrm{Fe}, \mathrm{Mn}$ and $\mathrm{Zn}$ by shoot, the control treatments were also significantly higher in the entire trials. The uptake of $\mathrm{N}, \mathrm{P}, \mathrm{Mg}$ and $\mathrm{Mn}$ by the root in the greenhouse revealed that there were no significant differences among the various treatments while in $\mathrm{K}, \mathrm{Na}$, $\mathrm{Fe}$ and $\mathrm{Zn}$ uptake, the $0 \mathrm{mgCr}$ was significantly higher. The uptake of these minerals by the root in the field showed that the $0 \mathrm{kgCrha}^{-1}$ was significantly superior than other treatments. The uptake of these minerals also decreased with increase in $\mathrm{Cr}$ concentration in the trials. The mineral components as well as the uptake by the shoot were higher than that of the root.

$\mathrm{Cr}$ content (\%) and uptake $\left(\mathrm{mgkg}^{-1}\right)$ by T. occidentalis: Table 4 shows the $\mathrm{Cr}$ content and uptake by the shoot and root. The accumulation of $\mathrm{Cr}$ by the shoot and root in the entire trials increased with increase in $\mathrm{Cr}$ treatment. However, the Cr content of the root in the trials was higher than that of the shoot. The Cr content of shoot in the

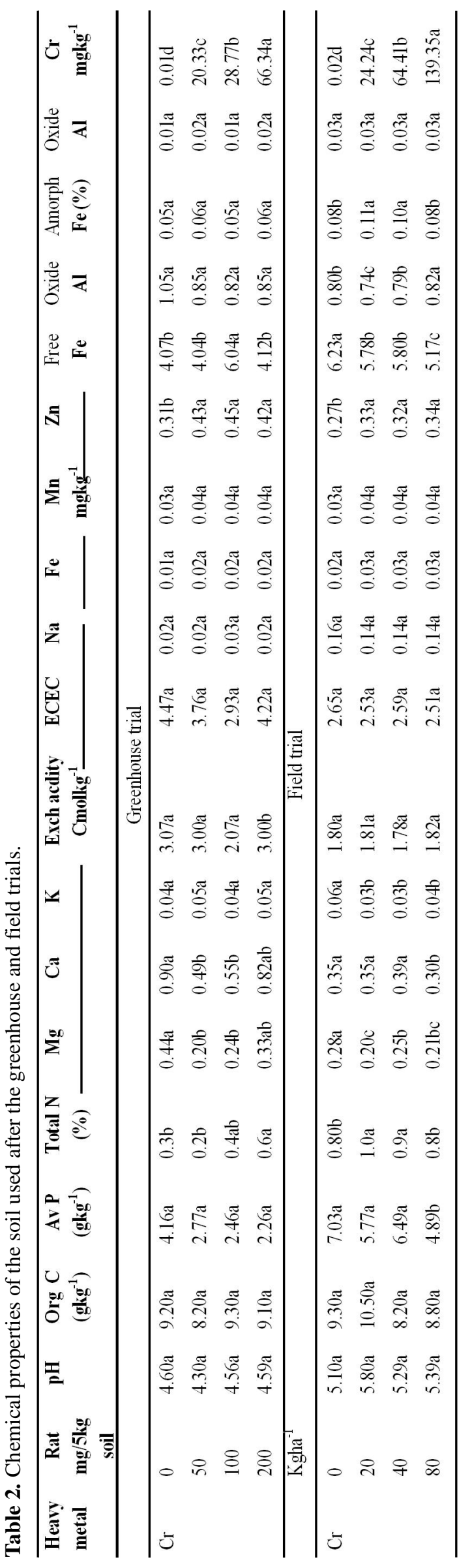



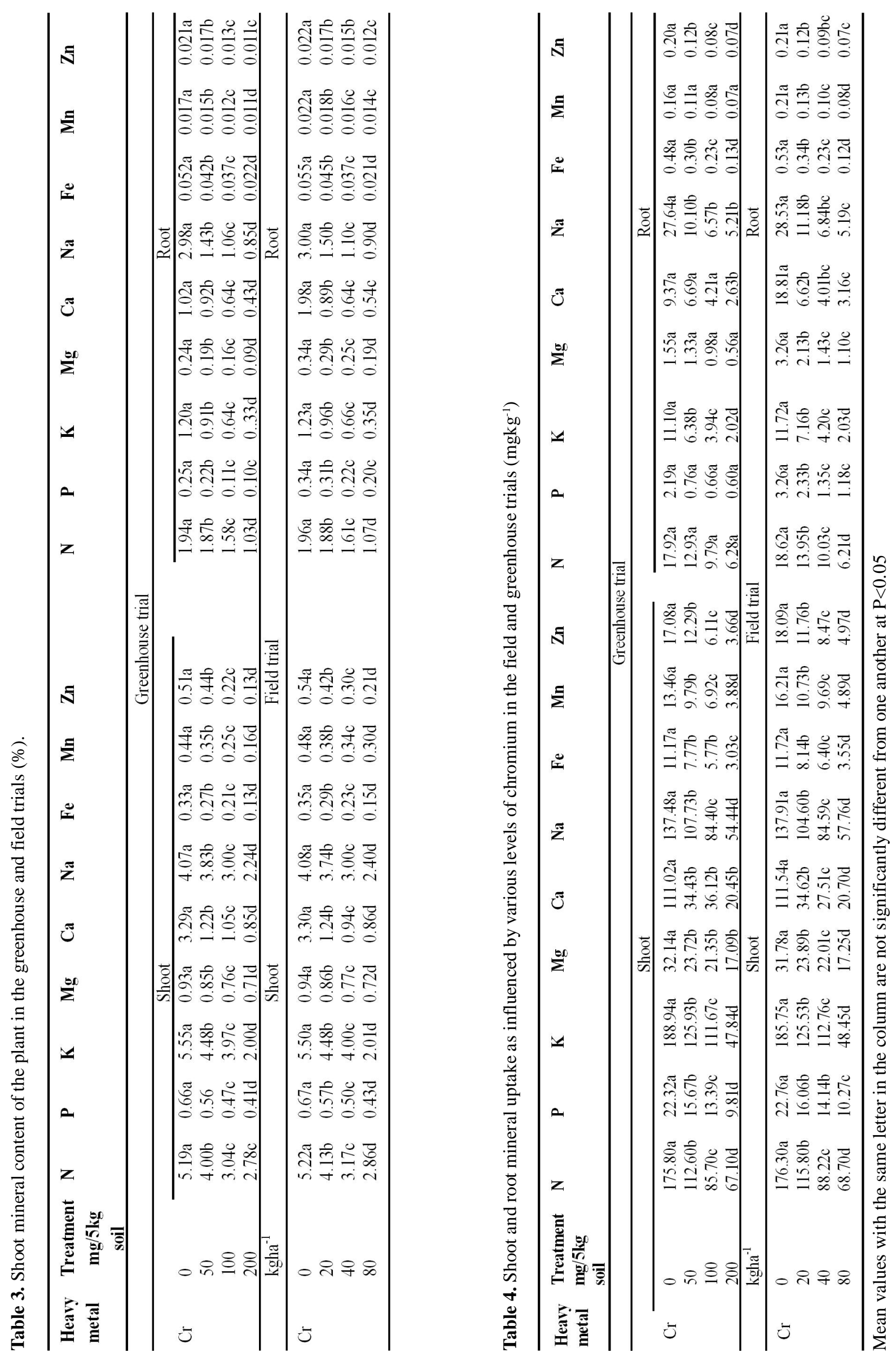
greenhouse and $\mathrm{Cr}$ content of root in field trial revealed the highest $\mathrm{Cr}$ treatments significantly higher than other treatments. While in the greenhouse, $\mathrm{Cr}$ content of the root recorded the $100 \mathrm{mgCr}$ and $200 \mathrm{mgCr}$ significantly higher. Similar trend was also recorded by shoot in the field trial with $20 \mathrm{kgCrha}^{-1}$ and $40 \mathrm{kgCrha}^{-1}$ significantly higher.

The uptake of $\mathrm{Cr}$ by the root in the entire trials revealed the control treatments significantly higher than other concentrations. The $\mathrm{Cr}$ uptake by shoot in the greenhouse showed that $50 \mathrm{mgCr}, 100 \mathrm{mgCr}$ and $200 \mathrm{mgCr}$ were significantly higher while $\mathrm{Cr}$ uptake by shoot in the field showed that the $40 \mathrm{kgCrha}^{-1}$ and $80 \mathrm{kgCrha}^{-1}$ were significantly higher. Higher $\mathrm{Cr}$ uptake by the root was however recorded compared to the shoot.

Effect of $\mathrm{Cr}$ on the crude protein content of $\mathrm{T}$. occidentalis: The crude protein content of the plant as influenced by $\mathrm{Cr}$ treatments is depicted in Table 4. The crude protein content of the shoot and root declined with increased $\mathrm{Cr}$ concentration. The shoot and root crude protein content in the entire trials revealed that the control treatments were significantly higher than other treatments in the trials. Higher crude protein was however recorded in the shoot than the root.

$\mathrm{E}$ ffect of $\mathrm{Cr}$ on the dry matter yield of T. occidentalis: The dry matter yield of the plant is shown in Table 5. The dry matter yield decreases as the concentration of $\mathrm{Cr}$ treatment increases. In the greenhouse, there were no significant differences among the various treatments in shoot and root dry matter. While in the field trial, the 0 $\mathrm{kgCrha}^{-1}$ treatment was significantly higher than other treatments in the shoot and root dry matter yields.

$\mathrm{E}$ ffect of $\mathrm{Cr}$ on plant height, stem girth, leaf ar ea and number of leaves of T. occidentalis: The growth parameters are shown in Figs. 1-8. The height, stem girth, leaf area and number of leaves increased with the advancement of the plant growth stages and were highest at harvest. The plant height, stern girth, number of leaves and leaf area decreased with increase in the application of the $\mathrm{Cr}$. At 30 days after transplanting in the greenhouse trial, the $0 \mathrm{mgCr}, 50 \mathrm{mgCr}$ and $100 \mathrm{mgCr}$ were significantly higher in leaf area (Fig. 1) and number of leaves (Fig. 3). While $0 \mathrm{mgCr}$ and $50 \mathrm{mgCr}$ were significantly higher than other treatments in plant height (Fig. 5) and stem girth (Fig. 7).

In the field trial, the $0 \mathrm{kgCrha}^{-1}$ and $20 \mathrm{kgCrha}^{-1}$ treatments were significantly higher in leaf area (Fig 2.), plant height (Fig. 6) and stem girth (Fig. 8). The $0 \mathrm{kgCrha}^{-1}$ treatment was however significantly higher than other treatments in number of leaves (Fig. 4). Generally, the control treatments were higher than other treatments in all the parameters at final harvest.

DISCUSSION

The properties of soil used indicated that the soil is low 
Table 6. Effect of chromium on the crude protein content of T. occidentalis in greenhouse and field trials.

\begin{tabular}{|c|c|c|c|c|c|c|c|}
\hline \multirow[b]{2}{*}{$\begin{array}{l}\text { H eavy } \\
\text { metal }\end{array}$} & \multirow{2}{*}{$\frac{\text { Treatment }}{\mathrm{mg} / 5 \mathrm{~kg} \text { soil }}$} & \multicolumn{2}{|c|}{ Greenhouse trial } & \multirow[b]{2}{*}{$\begin{array}{l}\text { H eavy } \\
\text { metal }\end{array}$} & \multirow{2}{*}{$\begin{array}{l}\text { Treatment } \\
\text { R ate } \mathrm{kgha}^{-1}\end{array}$} & \multicolumn{2}{|c|}{ Field trial } \\
\hline & & Shoot & R oot & & & Shoot & Root \\
\hline $\mathrm{Cr}$ & 0 & $32.44 \mathrm{a}$ & $12.11 \mathrm{a}$ & $\mathrm{Cr}$ & 0 & $32.61 \mathrm{a}$ & $12.25 \mathrm{a}$ \\
\hline & 50 & $25.02 \mathrm{~b}$ & $11.69 \mathrm{~b}$ & & 20 & $25.83 b$ & $11.73 b$ \\
\hline & 100 & $19.02 \mathrm{c}$ & $9.96 \mathrm{c}$ & & 40 & $19.81 \mathrm{c}$ & $10.07 \mathrm{c}$ \\
\hline & 200 & $17.40 \mathrm{c}$ & $6.42 \mathrm{~d}$ & & 80 & $17.86 \mathrm{~d}$ & $6.67 \mathrm{~d}$ \\
\hline
\end{tabular}

Mean values with same letter in the column are not significantly different from one another at $\mathrm{P}<0.05$

Table 7. Effect of chromium on the dry matter yield ( $\mathrm{g}$ ) of Telfaira occidentalis in greenhouse and field trials.

\begin{tabular}{|c|c|c|c|c|c|c|c|}
\hline \multirow[b]{2}{*}{$\begin{array}{l}\text { H eavy } \\
\text { metal }\end{array}$} & \multirow{2}{*}{ 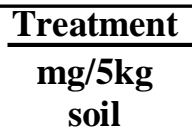 } & \multicolumn{2}{|c|}{ Greenhouse trial } & \multirow[b]{2}{*}{$\begin{array}{l}\text { Heavy } \\
\text { metals }\end{array}$} & \multirow{2}{*}{$\begin{array}{c}\text { Treatment } \\
\text { Rate } \\
\text { kgha }^{-1}\end{array}$} & \multicolumn{2}{|c|}{ Field trial } \\
\hline & & $\begin{array}{c}\text { Shoot dry } \\
\text { weight }\end{array}$ & $\begin{array}{c}\text { R oot dry } \\
\text { weight }\end{array}$ & & & $\begin{array}{c}\text { Shoot dry } \\
\text { weight }\end{array}$ & $\begin{array}{l}\text { Root dry } \\
\text { weight }\end{array}$ \\
\hline$\overline{\mathrm{Cr}}$ & $\overline{0}$ & $3.27 \mathrm{a}$ & $0.92 \mathrm{a}$ & $\mathrm{Cr}$ & $\overline{0}$ & $3.35 \mathrm{a}$ & $0.95 \mathrm{a}$ \\
\hline & 50 & $2.81 \mathrm{a}$ & $0.70 \mathrm{a}$ & & 20 & $2.80 \mathrm{~b}$ & $0.74 b c$ \\
\hline & 100 & $2.81 \mathrm{a}$ & $0.62 \mathrm{a}$ & & 40 & $2.82 \mathrm{~b}$ & $0.62 \mathrm{c}$ \\
\hline & 200 & $2.39 \mathrm{a}$ & $0.62 \mathrm{a}$ & & 80 & $2.41 \mathrm{c}$ & $0.58 \mathrm{c}$ \\
\hline
\end{tabular}

Mean values with the same letter in the column are not significantly different from one another at $\mathrm{P}<0.05$

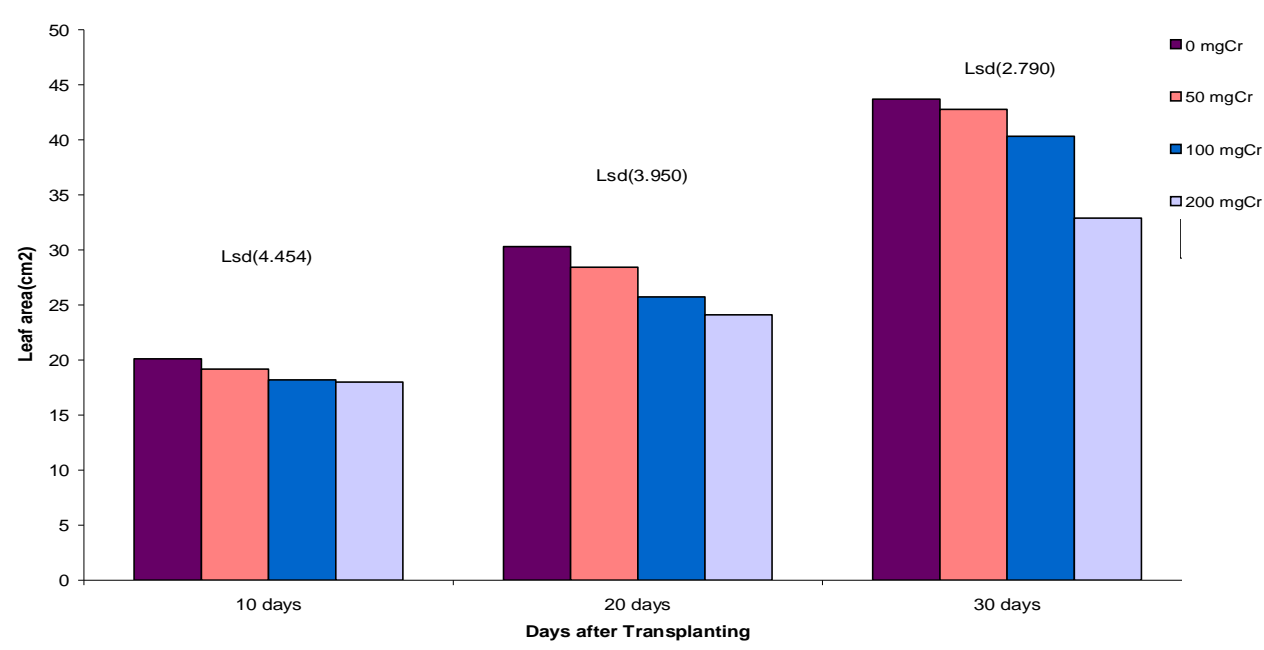

Fig. 1. Effect of chromium on leaf area of T. occidentalis in green house trial.

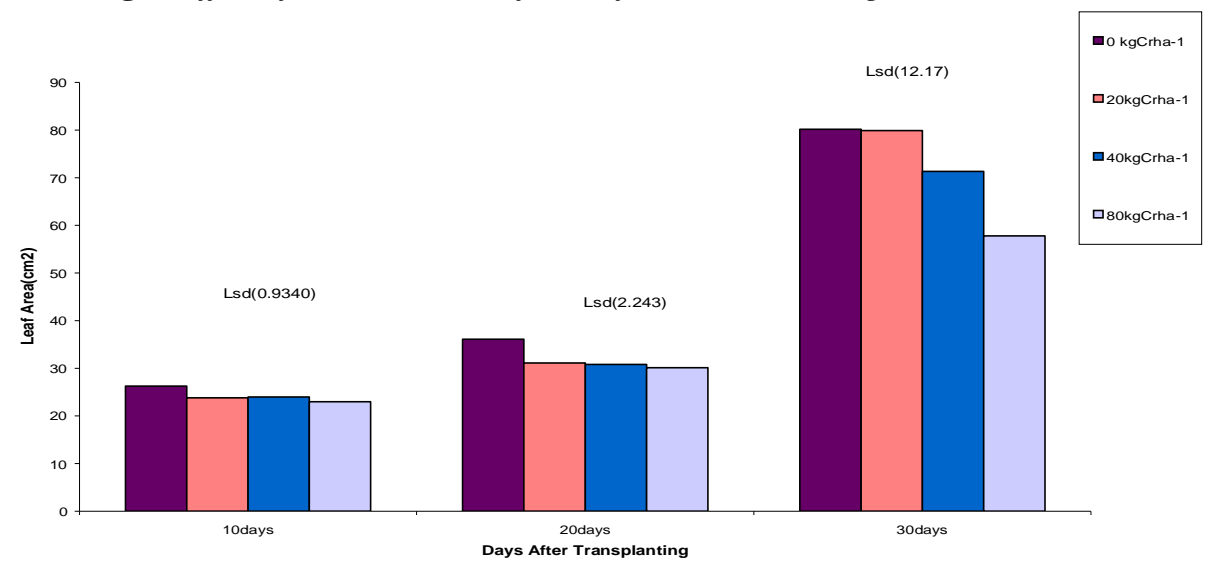

Fig. 2. Effect of chromium on leaf area of T. occidentalis in field trial.

in fertility that is typical of an Ultisol as shown by its low percent base saturation (less than 35\%). The low base saturation distinguishes it from alfisol (Brady and Weil, 2002). The reduction in some of the soil nutrient content such as $\mathrm{N}, \mathrm{P}, \mathrm{K}, \mathrm{Mg}, \mathrm{Ca}, \mathrm{Na}$ and organic carbon was not consistent. The fluctuation of these mineral nutrients may be tied to the plants' uptake at different levels of heavy metal applied. The decrease in oxides may be due to their 


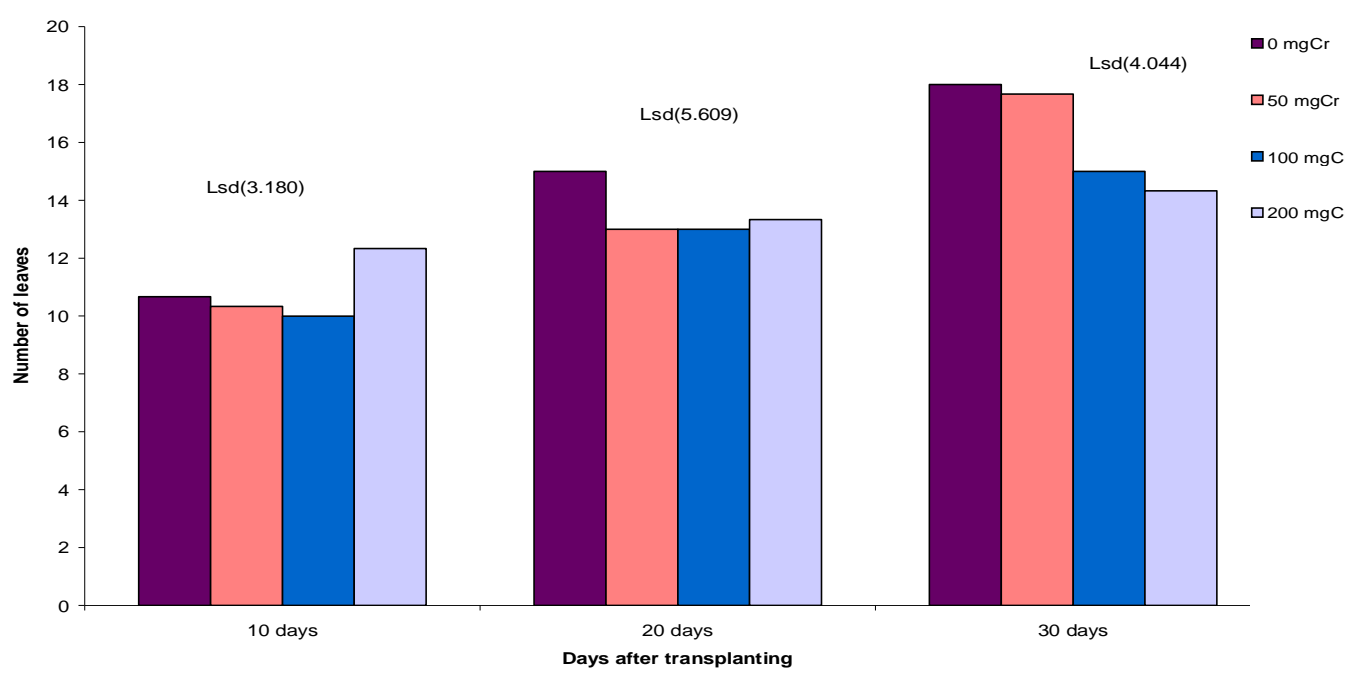

Fig. 3. Effect of chromium on number of leaves of T. occidentalis in green house trial.

solubility as a result of low $\mathrm{pH}$ in the soil used. Generally, oxides solubility is very low at the $\mathrm{pH}$ range of soils and depends on the particle size, crystallinity and the percent of Al substitution (Schwertmann, 1991). The $\mathrm{pH}$ of soil used may have favoured the reduction in the oxides. Similar result have earlier been reported by Schwertmann et al. (1985) who reported that the quantification of oxides in soils and sediments is often complicated by a considerable variation in crystallinity. The increase in the heavy metal content of the soil is attributed to the increase in the amount or concentration of $\mathrm{Cr}$ applied to the soil. Gundermann and Hactchinson (1995) and Tam and Singh (2004) have earlier reported elevated heavy metals in soil contaminated by heavy metal mine spoils. The declined in growth parameters is attributed to the influence of the metal especially in the higher dosage. This result further strengthens earlier report of Foy et al (1978) that heavy metals decrease plant vegetative growth. The reduced shoot and root biomass of the heavy metal plants in this study can also be due to specific toxicity of the metal to the plant, antagonism with other nutrients in the plants or inhibition of root growth in the soil. Azmat et al. (2006) also reported that heavy metals significantly depressed leaf sizes, stem and elongation of roots as compared to control in Phaseolus mungo and Lens culinaris plants. The decreased root growth could also be attributed to lack of oxygen as a result of $\mathrm{Cr}$ application. Roots, which become totally submerged in soil contaminated by heavy metals, will suffer from lack of oxygen and this will lead to slow growth and inhibitory effect of toxic metal on roots of plants (Jones et al., 1973). The $\mathrm{Cr}$ may have altered the levels of mineral elements in the roots by physically blocking mineral ions from absorption sites of roots. In the roots, the levels of minerals were reduced with increase in the Cr supplied. The inhibition of root growth as demonstrated by the root weight after exposure to the $\mathrm{Cr}$ may be related with decrease in $\mathrm{Ca}$ in the root tips of Telfairia occidentalis leading to decrease in cell division. Similar findings were earlier reported by Rout and Das (2003) with Norway spruce plants and with Brahmi plants (Pande et al., 2007). The observed actions in the crop appear to be indirect as

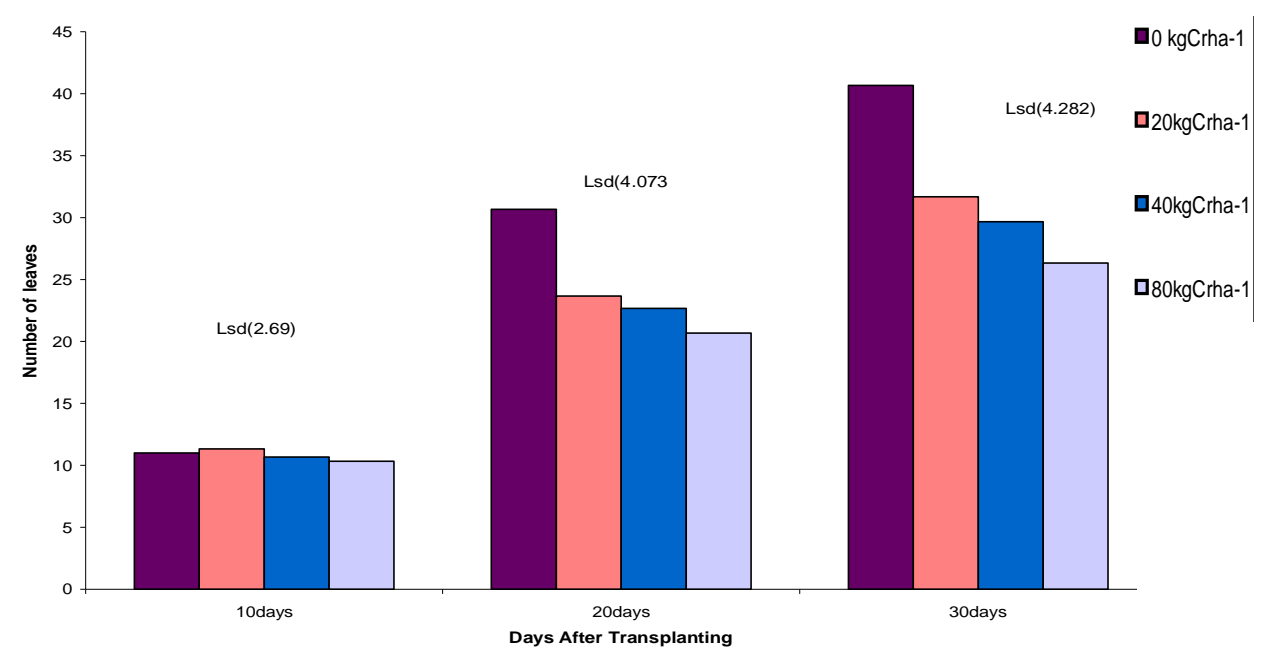

Fig. 4. Effect of chromium on number of leaves of T. occidentalis in field trial. 


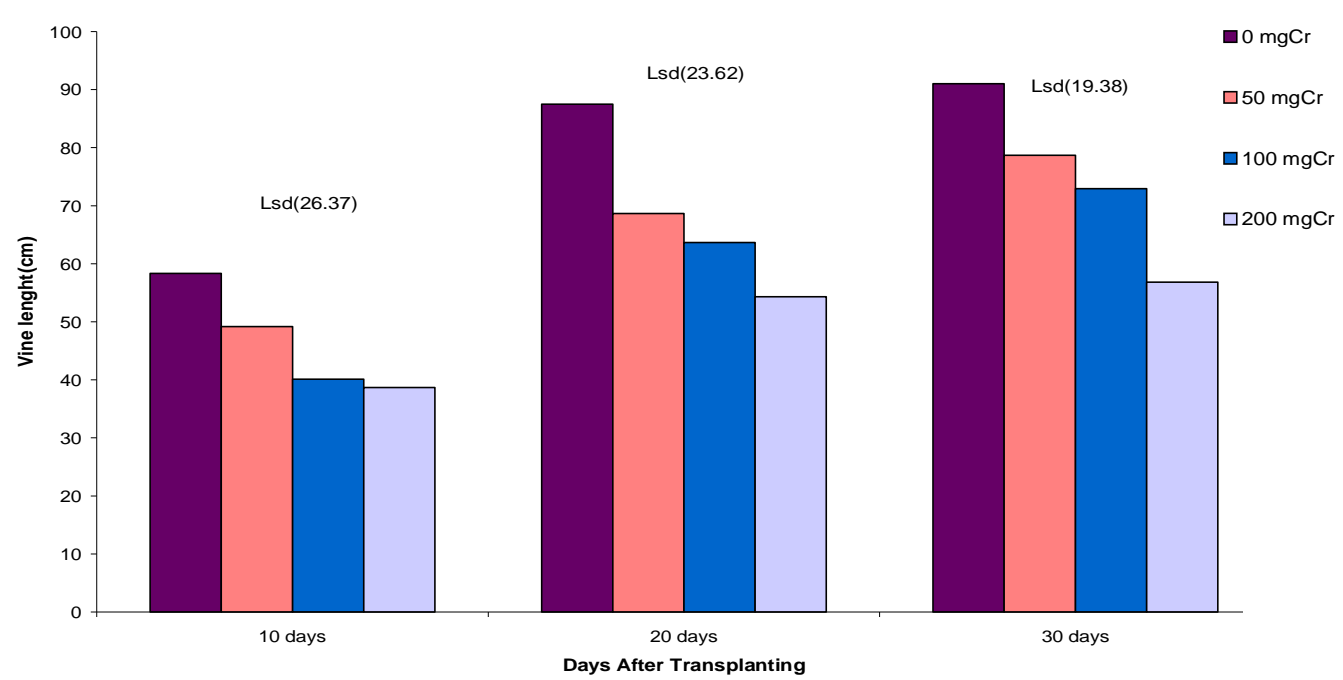

Fig. 5. Effect of chromium on the plant height of T. occidentalis in green house trial.

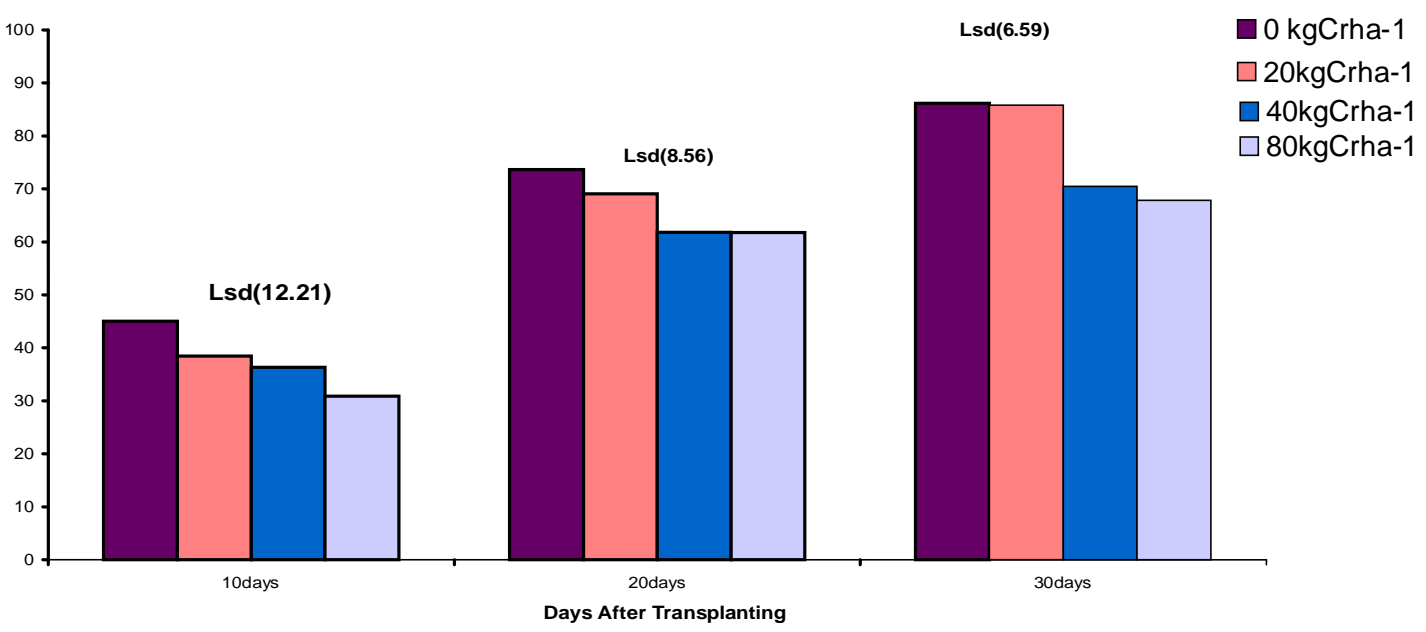

Fig. 6. Effect of chromium on the plant height of T. occidentalis in field trial.

a result of minerals imbalance within the tissue of Telfairia plants. The mineral imbalances brought significant changes in plant nutrient components. The reduction in $\mathrm{Fe}$ in both root and shoot in soil contaminated with the heavy metal may be due the presence of high concentration of $\mathrm{Cr}$, which induced Fe deficiency in the crop due to competition by the heavy metal for functional sites of Fe binding Hewit (1963). Iron is required for the synthesis of chlorophyll and is essential part of the cytochrome which serves as electron carrier in photosynthesis and respiration. Deficiency of $\mathrm{Fe}$ in the plant may have caused the inhibition of photosynthesis resulting in small size of leaves of plant as shown in the polluted soil. The decrease in the concentration of $\mathrm{Mn}$ may have caused reduction in the concentration of chlorophyll that may be related to the reduction in quantum yield of oxygen evolved in photosynthesis (Haider et al., 2006) and then depression in growth of Telfairia plant in soil treated with $\mathrm{Cr}$. The concentration of $\mathrm{Zn}$ may have been lowered due to the $\mathrm{Cr}$ applied, which may have resulted in the stunting of plant and leaf growth.
$\mathrm{Zn}$ as matter of fact is needed for the formation of hormone indoacetic acid, which is an enzyme activator. The increase in the $\mathrm{Cr}$ concentration may have led to decreased quantity of $\mathrm{Mg}$ in both root and shoot, which affected the process of photosynthesis as earlier observed and reported, by Haider et al. (2006). Reduction in nutrient content as well as in internal ratios of nutrients may have occurred in the Telfairia plants under $\mathrm{Cr}$ stress as observed earlier by Pinero et al. (2002). The higher $\mathrm{Cr}$ concentration may have damaged the tissue cells of vascular bundles, which resulted in the inhibition of conduction of water molecules from root to aerial parts of the plant hence there was reduction in plant nutrients. The deficiency of $\mathrm{Ca}$ generally results in an imbalance with $\mathrm{K}$ and $\mathrm{Mg}$ and it may have primarily affected leaf size and shape. Magnesium is also known to be a constituent of chlorophyll (Haider et al., 2006) and is needed for activation of many enzymes involved in energy transfer. A deficiency of $\mathrm{Mg}$ would have seriously affected the plant growth and development as photosynthesis is directly affected (Haider et al., 2006). 


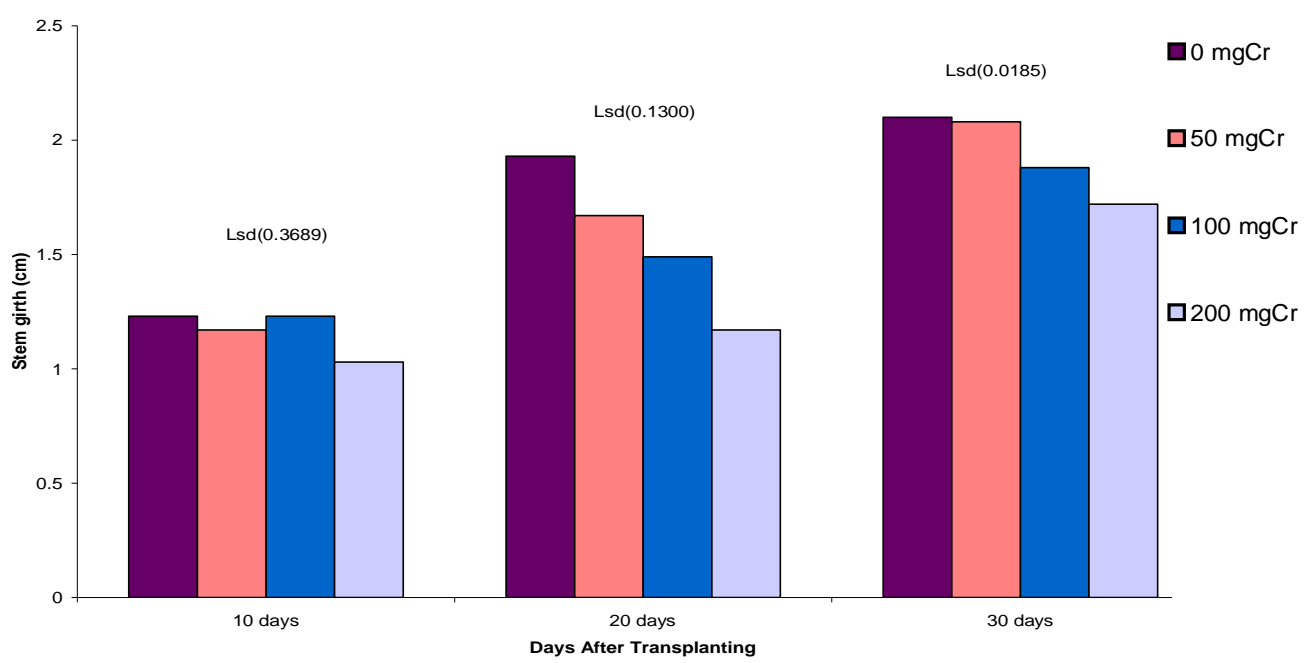

Fig. 7. Effect of chromium on the stem girth of T. occidentalis in green house trial.

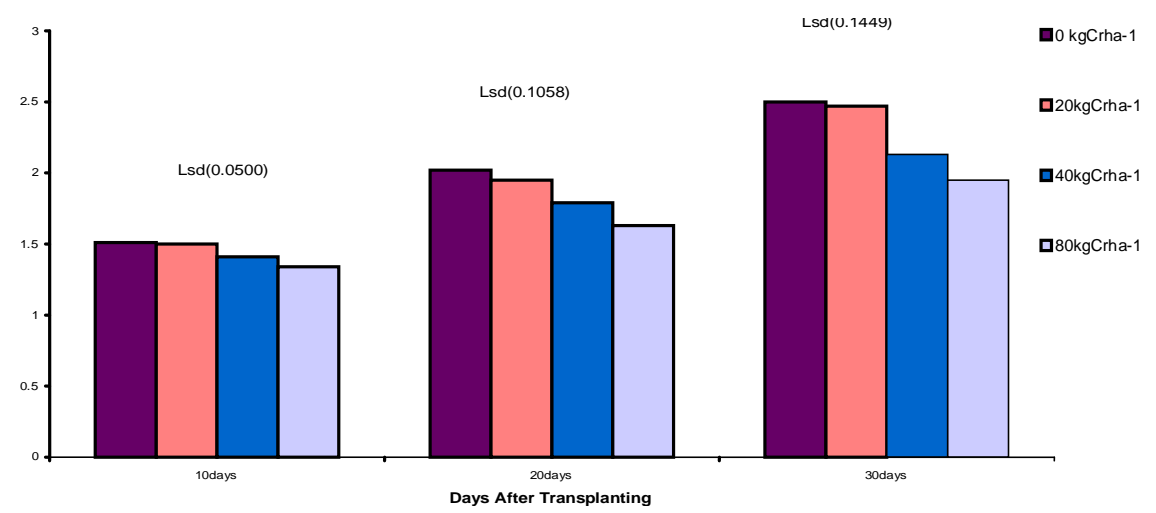

Fig. 8. Effect of chromium on the stem girth of T. occidentalis in field trial.

Phosphorus is known to be a constituent of ATP coenzymes and is very important in plant energy transfer system. A deficiency can slow growth considerably (Azmat and Haider, 2007) as demonstrated by the growth of Telfairia plant treated with higher $\mathrm{Cr}$ dose. This reduction in plant nutrients is similar to the findings of Eun et al. (2002) and Azmat et al. (2006). The decrease in the uptake of nutrient by shoot and root may be attributed to a decrease in nutrient content as a result of increase in the $\mathrm{Cr}$ application. The decrease in $\mathrm{Fe}, \mathrm{Mn}$ and $\mathrm{Zn}$ uptake may be due to interference of the heavy metals with the metabolism of mineral nutrients. Sharma and Pant (1994) reported reduced uptake of $\mathrm{Fe}, \mathrm{Mn}$ and $\mathrm{Zn}$ in maize due to $\mathrm{Cr}$ treatments.

The protein content of both the shoot and root also decreased with increase application of the heavy metals. This result is similar to the finding of Okyto (1997) with $39.2 \%$ crude protein and Oboh (2005) who reported 38\% crude protein in Telfairia plants grown in soils not contaminated with heavy metals. The depression of the protein content is attributed to the decrease in uptake of some minerals by the plant. For instance, the $\mathrm{K}$ acts as a coenzymes or activator of many enzyme systems (Kabata-
Pendias and Pendia, 1992). Higher K levels according to Schreinemaker (1984) are needed for protein synthesis. In this study, this excess $\mathrm{Cr}$ applied may have caused leakage of $\mathrm{K}$ ions, which may have depressed protein formation in both shoot and root.

There was a significant difference between the shoot and root organs of the plant with respect to applied $\mathrm{Cr}$ and resultant accumulation trend of $\mathrm{Cr}$. Higher $\mathrm{Cr}$ content was found in the root than the shoot making the plant Telfairia occidentalis a metal excluder. A metal excluder prevents metal from entering their aerial part or maintains low and constant metal concentration over a broad range of the concentration in soil and they mainly restrict metal in their root (Raskin et al., 1994). The ability of a metal excluder to restrict heavy metals to root is based on the mechanisms that actively growing roots provide a barrier, which restricts the movement of heavy metal to above ground parts of plants. Davies and White (1981) with assorted vegetables and Kachenko and Singh (2004) with broadleaf vegetables and herbs grown in soils with high concentration of heavy metals have earlier reported higher levels of heavy metals in their roots. 


\section{Conclusion}

The physiological, nutritional implications of $\mathrm{Cr}$ on Telfairia plant and on some soil physico-chemical properties were studied. The application of $\mathrm{Cr}$ had an effect on the plant performance by altering the rate of nutrient uptake, synthesis and translocation of vital mineral elements in the plants. The plants treated with the $\mathrm{Cr}$ had a declined vegetative growth, dry matter accumulation, nutrient elements as well as reduced nutrient uptake showing the existence of interaction between the $\mathrm{Cr}$ with the nutrient elements in the soil. Significant differences between the root and shoot accumulation of $\mathrm{Cr}$ was also recorded with the root of the plant accumulating higher $\mathrm{Cr}$ than the shoot. There were fluctuations in most mineral components of the soil. The accumulation of $\mathrm{Cr}$ in the control plants was low and compared favourably well with the WHO (1984) maximum acceptable level of $0.3 \mathrm{mgkg}^{-1}$ for most vegetables whereas those treated with the $\mathrm{Cr}$ had higher levels of the metal making it hazardous to health when regularly consumed. It then means that planting of Telfairia occidentalis near or in refuse dumps may not be advisable since such areas are likely to contain high amounts of this metal. However, this plant could be used to phytoremediate $\mathrm{Cr}$ contaminated soils.

\section{REFERENCES}

Association of Official Analytical Chemists (AOAC) (1970). Official methods of analysis Ed 11 Washington D. C.

Azmat, R and Haider, S (2007). Pb Stress on phytochemistry of seedlings Phaseolus mungo and Lens culinaris. Asian J ournal of Plant Science, 6 (2) : 332-337

Azmat, R. Haider, S and Askari, S. (2006). Phytoxicity of Pb $\mathrm{I}$ : Effects of $\mathrm{Pb}$ on germination, growth, morphology and histomorphology of Phaseolus mungo and Lens $\mathrm{C}$ ulinaris. Pakistan J ournal of Biological Science, 9:979-984.

Azmat, R. and Khanum, R. (2005). Effect of chromium on uptakes of minerals atoms in bean plant. Pakistan J ournal of Biological Sciences, $8: 281-283$.

Black, C.A. (1965). Methods of soil analysis.Agronomy No 9 Part 2. America Society of Agronomy Madison Wisconsin. 1162-1164.

Brady, N.C. and Weil, R.R. (2002).The nature and properties of soils. $13^{\text {th }}$ Edition. Hall Upper Saddle River, New Jersey. pp. 960.

Bray, R. H. and Kurtz, L. T. (1945). Determination of total organic and available forms of phosphorus in soils. Soil Science, $59: 39-48$

Davis, B.E. and White, H.M. (1981). Trace elements in vegetables grown on soils contaminated by base metal mining. J ournal of Plant Nutrition, 2: 387-397

Day, P.R. (1965). Particle fractionation and particle size analysis: In methods of soil analysis, (C.A. Black Ed).Agronomy No 9 Part 1. American Society of Agronomy Madison, Wisconsin, 545-567.

Eun, S.O., Youn, H.S. and Lee, Y. (2002). Lead disturbs microtubile organization in root meristem of Zea mays.
Physiology of Plants, 110:357-365.

Foy, C.D., Chaney, R.L. and White, M.C. (1978). The physiology of metal toxicity in plants. Annual Review of Plant Physiology, 29:511-566.

Gundermann, D.G. and Hutchinson, T.C. (1995). Changes in Soil Chemistry 20 years after the Closure of nickel-copper smelter near Sudbury, Ontario, Canada. Geochemical Exploration, 52:231-236.

Haider, S., Kanwal, S., Uddin, F. and Azmat, R. (2006). Phytoxicity of $\mathrm{Pb}$ II: Changes in chlorophyll absorption spectrum due to toxic metal $\mathrm{Pb}$ stress on Phaseolus mungo and Lens culinaris. Pakistan J ournal of Biological Science, 9:2062-2068

Hewit, E.J. (1963). The essential nutrient elements requirements and interactions in plants. Vol. 3 In plant physiology (A. Treaties steward FC (ed) ) Academic Press New York, 137 - 360.

International Institute of Tropical Agriculture (IITA) (1979). Selected methods for soil and plant analysis. Manual Series No 1. pp. 70.

Jackson, M.L.(1962). Soil chemical analysis. Prentice Hall, New York. 263-268.

Jones, L.H.P. Clement, C.R and Hoope, M.J.(1973). Lead uptake from solution by perennial ryegrass and its transport from root and shoots. Plant Soil, 38:403-414.

Kabata-Pendia, A and Pendias, H. (1992). Trace elements in soils and plants. $2^{\text {nd }}$ Edition CRC Press Boca Raton, London..

Kachenko, A and Singh B. (2004). Heavy metals contamination of home grown vegetables near metal smelter in NSW. SuperSoil: 2004 Australian/New Zealand Soil Conference, 5-9 December, 2004, Adelaide.

Mclean, E.O. (1965). Aluminium. In: Methods of soil analysis(Ed C.A Black) Agronomy No 9 Part 2. American Society of Agronomy, 978-998.

Murphy, J and Riley, J.P. (1962). Analytical chemistry. Acta 27:31-36.

Oboh, G. (2005). Nutritional and safety evaluation of some tropical green leafy vegetables. J ournal of F ood Technology, 3 (3): 389-392.

Okyto, B.N. (1997). Neglected plants of horticultural and medicinal importance in Traditional farming system in Tropical Africa. Acta H orticulture, 131-149.

Pande, P; Chand S; Vinod, K., Anwa, M. and Patra, D.D. (2007). Influence of Chromium with Vermicompost on growth and accumulation by Brahmin.C ommunication in Soil Science and Plant Analysis, 38 : 2815-2829.

Payne, R.W (2002). Gentstat 6.1: Reevence manual VSN International Ltd. Oxford.

Pinero H.J.L., Miti, R.K., Julia-Verdestar, M.A., Diaz G.G., Dnzalez, A.N., Cardenas Avila, M.L. and Orough- Bakhih, R. (2002). Effect of $\mathrm{Pb}$ and $\mathrm{Cd}$ on seedlings, growth, chlorophyll and protein contest of common bean. Phascolus vulgaris, Alfa alfa (Medigago sativa), Avena (Avena santiva and rye grass (Lolum multiflorum) selected as hyper accumulator of heavy metal. Research on Crops, $3: 473$ 480.

Raskin, I., Kumar, P.B.A., Dushenkovs, N. and Salt, D. (1994). Bio-concentration of heavy metals by plants. Current O pinion on Biotechnology, $5: 285-290$.

Schreinemakers, W. A. (1984). Effect of metal ions on growth 
and on ion absorption by spirodela polyrbaza (L) Schleiden: Effects of iron, magnesium and zinc. Z. Pflanzen Physiology, 114:123-129.

Schwatmann, U; Philippe, C. and Murad, E. (1985). Properties of goethite varying in crystalinity Clays and C lay M inerals, 33:369-378.

Schwertmann, U. (1991) Solubility and dissolution of iron oxides Plant and Soil, 130:1- 25.

Shaganas, B.B; Thangaval, P and Suhburam, V. (1997). Toxicity of neolan grey to Vigna radiata co.3. Pollution Research, 16(1):25-28.

Sharma, D.C and Pant, R.C. (1994). Chromium uptake, its effect on certain plant nutrients in maize (Zea mays L) W Gang 5). J ournal of Environmental Science and Heaths, 29 (5) : $941-948$
Soon, Y. K. and Abboud, S. (1993). Cadmium, chromium, lead and nickel In: Soil sampling and methods of soil analysis (eds M.R. Carter). Canadian Society of Soil Science, 101-108 Subramani, A., Saravanan, S., Taraizhuiyay, P. and Lakshmanalharg, A.S. (1997). Influences of heavy metals non germination and early seedlings growth of Vigna mungo L. Pollution Research, 16 (1): 29-31.

Tam, Y.L and Singh, B. (2004). Heavy metals availability at industrially contaminated soils in NSW, Austral: In A.L. Juhaz, G Magesan and R. Naidu (eds). Waste Management, Science. Publishers Plymouth, 97-120.

WHO (World Health Organization) (1984). Guidelines for soil, water and plant qualitVol. 1 Recommendation W.H.O. Geneva, 13 pp. 130. 